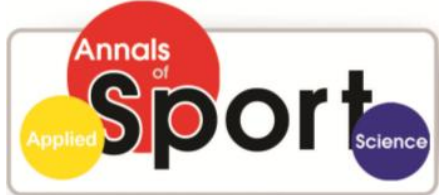

www.aassjournal.com

e-ISSN: 2322-4479

p-ISSN : 2476-4981

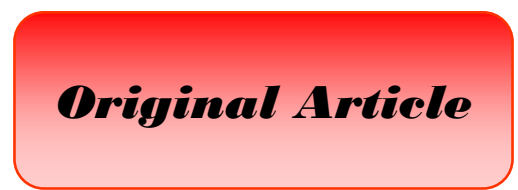

Received: 01/04/2015

Accepted: 29/10/2015

\title{
Assessment and Comparison of Visual Skills among Footballers
}

\author{
${ }^{1}$ Robabeh Rostami* ${ }^{*}{ }^{1}$ Hamid Mohammadi, ${ }^{2}$ Mahboobeh Alborzi
}

1. Department of Physical Education and Sport Sciences, Shiraz University, Shiraz, Iran.

2. Department of Education Foundations, Shiraz University, Shiraz, Iran.

\begin{abstract}
Like bodily, physiological, and psychological skills which are commonly assessed in professional sport, assessment of visual skills is also of high importance. In this regard, and in order to organize teams efficiently, the skills of each player, considering his/her post in the pitch, should be developed for superiority over the opponent. The present study attempts to clarify if there is a meaningful difference between visual skills of players, by considering their posts, age groups and sport records. A group of 100 professional footballers with average age of $25.09 \pm 4.47$, average height of $178.66 \pm 6.53 \mathrm{~cm}$, and average weight of $74.80 \pm 7.03$ were selected, using an available sampling method. Wilson and Falkel's Sports Vision Test (2004), widely used in many researches, was the assessment tool of visual skills in this research, and is comprised of six skills of accommodation or focusing, tracking, vergence, sequencing, eye-hand coordination and visualization. The results indicated a meaningful difference which existed only in terms of tracking $(p \leq 0.04)$ between adults and the youth, of which the superiority was shown by the first group. No meaningful difference was observed between post in the pitch (goalkeeper, defender, midfielder and forward) and sport record in terms of visual skills (including accommodation / focusing, tracking, vergence, sequencing, eye-hand coordination and visualization). The results of this study demonstrated a similarity between the exercise programs of team members. Coaches should notice that every post has different characteristics and the fact that in addition to specific physiological needs and skills, each post requires visual skills, and this marks the necessity for specialized planning for every post during the training sessions.
\end{abstract}

Key Words: Visual Skills, Footballers, Assessment.

Corresponding Author:

Robabeh Rostami

E-mail: rostami@shirazu.ac.ir 


\section{INTRODUCTION}

Football is one of the most popular sports in the world, in which men, women, children and young people participate with different levels of skill. The posts of goalkeeper, defender, midfielder and forward are defined for this sport $(1,2)$, and players are required to carry out different technical and tactical duties in line with the aforementioned posts $(3,4)$. Like other sports, there has been an increase in the speed of movement or the rhythm of the modern football over the past years. The present footballers, accordingly, are able to run faster, perform technical skills more rapidly, and implement better the tactical decisions (5). In this regard, coaches seek appropriate ways of their athletes' superiority in different matches.

For this purpose, numerous professional football schools have been established in recent years, around the world, to train young talented players. These schools have started various activities in order to increase the skill and readiness and talent survey of their young players, including preparation of technical and skill standard norms and assessment of different skills (6). Given its increasing growth among teenagers and youths across the country, it seems necessary to go over this issue in depth and investigate the analytical dimensions, such as talent survey and optimization, benefiting from physical capitals of athletes through scientific methods, and to identify and eliminate the current setbacks (6). Although new capacities and considerable infrastructures are developed domestically for the aforementioned purpose, few studies have been carried out on eye and vision, in terms of both health and care or analytical aspects. Vision has great effect on the sport and has many interactions with it, and may be of help, especially to the athletes in hub and team sports, in addition to the aforementioned issues. An assessment of the visual skills in each sport is carried out, usually considering the type and nature of that particular sport (7, 8). It seems football leaves particular challenges to the vision system of the footballer, such as eye-foot and eye-hand coordination, which is a basic requirement for all athletes. This sport also needs imagery and visualization skills, however, these skills are barely known as a sports vision skill (8).

Some evidences have indicated that the visual system could be improved like the other systems of the body by using particular visual exercises $(9,10)$. By exposing these muscles to exercise and increasing their speed, fixation of visuals or judgment on the moving ball may be performed with higher accuracy, and the player could be able to react more quickly and more accurately during a match (8). It could also ease the preparation for the match as well (11-13). In other words, this helps the athlete to employ the concepts suitably in his/her sport after acquiring them.

On the other hand, it also improves the athlete's ability to concentrate on the desired duty, and to keep easier at bay, the irrelevant information from fans or spectators or unrelated colors (14). Researches in this regard have shown that the players who enjoy more integration and interaction between vision and other senses perform better in sports. These studies advised the use of specialized exercises to improve the mentioned interactions $(10,15,16)$, although there are few evidences on examining the visual skills among footballers.

Du Toit et al. (2009) reported in an article titled "visual skills assessment among footballers" with the age range of 12 to 20 years old, that visual skill improved with aging, while they did not observe any meaningful difference in different posts (17). In a research on the relationship between visual skill and posts of Olympic field hockey players, Wimshurst, Sowden, and Cardinale (2012) reported no difference in visual skills in different posts (18). 
When athletes were exposed to a visual skill computer program, higher improvements were witnessed in visual skills of goalkeepers compared to the other posts (18). In a study which investigated the effects of visual awareness training on improving the implementation of the skills of hockey players, Calder (1997) indicated no meaningful difference in the posts of players (19). It is noteworthy at this point that not all athletes possess the same visual-perception and visual-motor skills (20), and vision plays a more important role in ball, Racquet, and team sports than other senses; in these sports, the athlete should process the visual information in a short time and decide (21, 22 ), and exercise can aid in improving visual abilities, remarkably (14).

Given the importance of identifying visual skills in different walks of sports community which has been less considered by coaches and players, probably resulting from lack of studies to show advantages of visual skills, and also on the other hand, uncertainty in the results of former researches, lack of using field visual test for assessment of visual skills, and that many former researches have investigated the physiological characteristics in different posts during the match $(23,24)$, and the shortage of studies and less information on visual skills of the players and the current gap in this connection, the present study investigates the visual skills of footballers in terms of their ages, posts in the match, and sport records. No research has been carried out regarding the aforementioned. The results of this study may shed light on the importance of visual skill in footballers, because underdevelopment in each visual skill highly affects sport vision and consequently, the sport performance.

\section{MATERIALS AND METHODS}

This is a causal comparative research which is cross-sectional one and has been applied in terms of type and the achieved results, respectively.
Participants. The statistical population of the study comprised 100 professional footballers selected from the 250 from Shiraz in 2014, using available sampling from among the players active in the Iran's premier and first division leagues (50 players from the first and 50 from the latter).

Study Design. The players free from any record of disease, visual impairments and drug addiction participated in this study after filling the consent forms. For assessment of visual skills of the participants, Wilson and Falkel's vision test (2004) was used (8), which has been employed repeatedly in numerous studies, such as Mohammadi et al. (2015), Fourie (2013), and Du Toit et al. $(2012,2012)(25-28)$. In order to examine the psychometric characteristics of this test, the three methods of content, correlation between graders, and retest, commonly used in Iran were approved completely (25-28).

This test has been paid much attention to in researches because of its reliability and cost efficiency compared to other similar tests which are run clinically in optometry centers to assess certain visual skills. This test is made up of six sub-tests of accommodation or focusing, tracking, vergence, sequencing, visualization, and eye-hand coordination. Following the completion of each test, the participants began the next sub-test after a one-minute interval. The participants repeated each test twice, of which the average scores were recorded, while the time duration of implementation of the test for each participant was reported as 15 to $20 \mathrm{~min}$ (8).

Statistical Analysis. IThe collected data was analyzed using the statistical software of SPSS (version 16). Descriptive statistics and inferential statistics (ANOVA test) were use in the meaningful level of $p \leq 0.05$, respectively for calculation of mean, standard deviation of measurable descriptive features including age, height, and weight, and comparison of visual skills of the players, given their posts, sport records, and ages. 


\section{RESULTS}

The descriptive data indicated a similarity between the groups under study in terms of age, height, and weight (Table 1).

Given the age, the youth demonstrated better performance in the visual skills of accommodation or focusing and visualization, while adults exhibited better performance in visual skills of tracking, vergence, sequencing, and eye-hand coordination; however, the differences were statistically meaningful $(\mathrm{p}=0.04)$ only in tracking skill (Figure 1).

Table 1. Descriptive data of demographic variables of participants based on sport record, post, and age group

\begin{tabular}{cccccccc}
\hline & \multicolumn{2}{c}{$\begin{array}{c}\text { Age } \\
\text { (years) }\end{array}$} & \multicolumn{2}{c}{$\begin{array}{c}\text { Weight } \\
\text { (kg) }\end{array}$} & \multicolumn{2}{c}{$\begin{array}{c}\text { Height } \\
\text { (cm) }\end{array}$} \\
\hline Groups & $\mathrm{n}$ & $\mathrm{M}$ & $\mathrm{SD}$ & $\mathrm{M}$ & $\mathrm{SD}$ & $\mathrm{M}$ & $\mathrm{SD}$ \\
\hline Premier league & 51 & 25.78 & 4.17 & 76.18 & 5.14 & 179 & 7.42 \\
\hline First division league & 49 & 24.37 & 4.69 & 73.38 & 8.38 & 178 & 5.52 \\
\hline Forward & 19 & 24.05 & 5.39 & 71.63 & 8.77 & 179 & 7.56 \\
\hline Midfield & 45 & 25.02 & 4.40 & 74.07 & 7.42 & 177 & 5.65 \\
\hline Defender & 27 & 25.18 & 3.86 & 76.55 & 4.26 & 178 & 5.77 \\
\hline Goalkeeper & 9 & 27.33 & 4.27 & 79.89 & 3.1 & 187 & 3.64 \\
\hline Youth & 38 & 20.53 & 2.88 & 70.83 & 8.66 & 176.42 & 5.96 \\
\hline adult & 62 & 27.89 & 2.53 & 77.24 & 4.34 & 183.03 & 6.53 \\
\hline
\end{tabular}

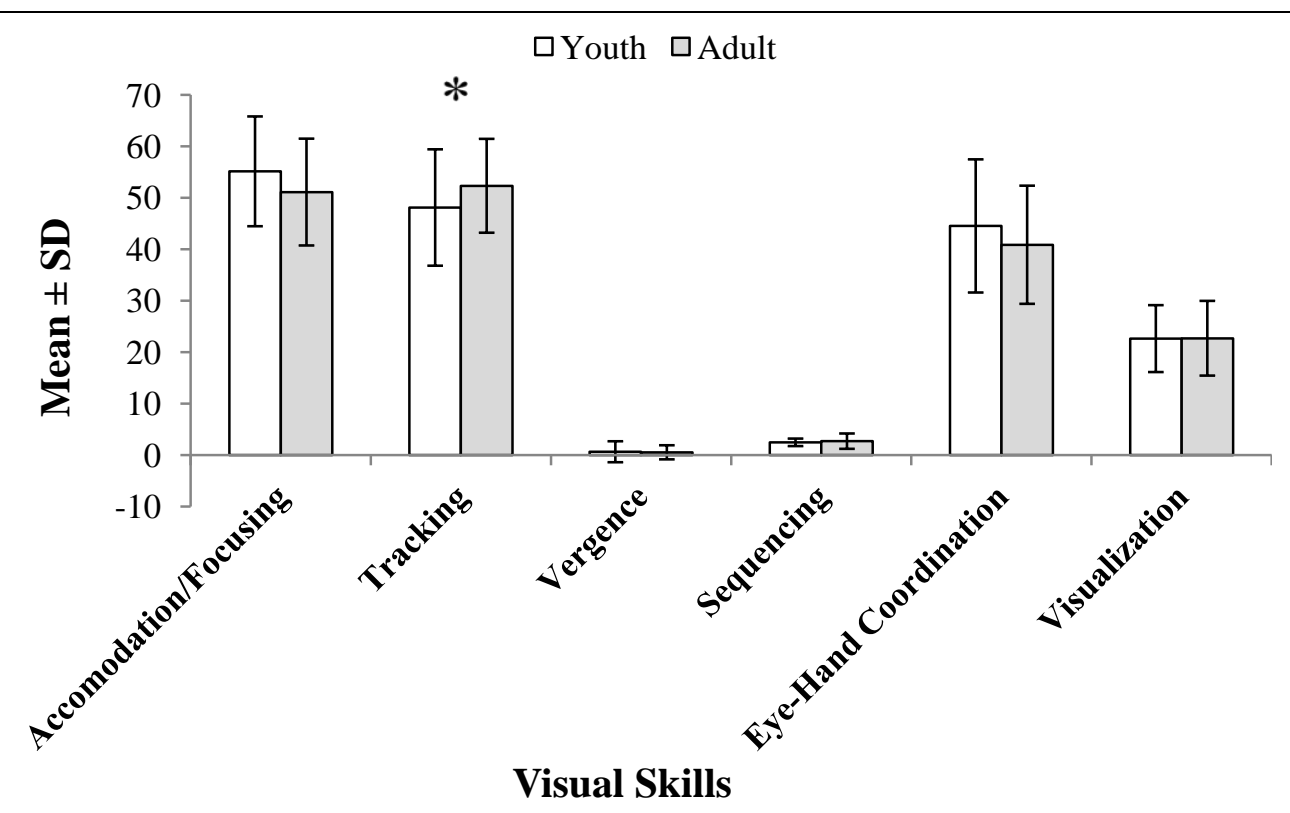

Figure 1. Comparison of visual skills of footballers based on age group. *: significant at $\mathrm{p}<0.05$.

Results of one-way ANOVA indicated a difference between posts in terms of visual skills, and that midfielders exhibited better performance in visual skills of accommodation
/ focusing, tracking, sequencing, visualization, and the goalkeepers exhibited a better performance in vergence and eye-hand coordination, compared to other posts, 
however, this difference was not statistically meaningful (Table 3).

Table 3. Results of one-way variance analysis to compare scores of visual skills of footballers based on posts

\begin{tabular}{|c|c|c|c|c|c|}
\hline Visual skills & Posts of footballers & Mean & SD & $\mathrm{F}$ & $\mathrm{p}$ \\
\hline \multirow{4}{*}{ Accommodation/Focusing } & Forward & 52.53 & 9.65 & \multirow{4}{*}{0.06} & \multirow{4}{*}{0.98} \\
\hline & Midfield & 52.53 & 10.61 & & \\
\hline & Defender & 53.52 & 11.37 & & \\
\hline & Goalkeeper & 53.44 & 11.62 & & \\
\hline \multirow{4}{*}{ Tracking } & Forward & 49.16 & 10.83 & \multirow{4}{*}{0.35} & \multirow{4}{*}{0.79} \\
\hline & Midfield & 51.80 & 9.43 & & \\
\hline & Defender & 50.33 & 10.99 & & \\
\hline & Goalkeeper & 49.78 & 10.96 & & \\
\hline \multirow{4}{*}{ Vergence } & Forward & 0.21 & 0.92 & \multirow{4}{*}{0.9} & \multirow{4}{*}{0.44} \\
\hline & Midfield & 0.78 & 2.04 & & \\
\hline & Defender & 0.63 & 1.57 & & \\
\hline & Goalkeeper & 0.00 & 0.00 & & \\
\hline \multirow{4}{*}{ Sequencing } & Forward & 2.55 & 0.66 & \multirow{4}{*}{0.12} & \multirow{4}{*}{0.95} \\
\hline & Midfield & 2.69 & 1.78 & & \\
\hline & Defender & 2.52 & 0.56 & & \\
\hline & Goalkeeper & 2.55 & 0.39 & & \\
\hline \multirow{4}{*}{ Eye-Hand Coordination } & Forward & 42.69 & 13.40 & \multirow{4}{*}{1.3} & \multirow{4}{*}{0.27} \\
\hline & Midfield & 41.98 & 9.87 & & \\
\hline & Defender & 44.64 & 14.18 & & \\
\hline & Goalkeeper & 35.50 & 12.44 & & \\
\hline \multirow{4}{*}{ Visualization } & Forward & 23.90 & 8.88 & \multirow{4}{*}{0.27} & \multirow{4}{*}{0.85} \\
\hline & Midfield & 22.18 & 6.36 & & \\
\hline & Defender & 22.67 & 7.15 & & \\
\hline & Goalkeeper & 22.42 & 5.11 & & \\
\hline
\end{tabular}

The results of independent t-test suggested that, given the sport records, no meaningful differences were observed in visual skills of accommodation/focusing, tracking, vergence, sequencing, eye-hand coordination, and visualization of footballers (Table 2):

Table 4. Comparison of visual skills of footballers based on sport record

\begin{tabular}{|c|c|c|c|c|c|}
\hline Visual skills & League Type & Mean & SD & $\mathbf{t}$ & $\mathbf{p}$ \\
\hline \multirow{2}{*}{$\begin{array}{l}\text { Accommodation/ } \\
\text { Focusing }\end{array}$} & First Division & 52.59 & 9 & \multirow{2}{*}{0.26} & \multirow{2}{*}{0.79} \\
\hline & Premier & 53.16 & 12 & & \\
\hline \multirow{2}{*}{ Tracking } & First division & 51.22 & 10.04 & \multirow{2}{*}{0.48} & \multirow{2}{*}{0.63} \\
\hline & Premier & 50.23 & 10.37 & & \\
\hline \multirow{2}{*}{ Vergence } & First division & 0.75 & 2.03 & \multirow{2}{*}{1.16} & \multirow{2}{*}{0.25} \\
\hline & Premier & 0.37 & 1.16 & & \\
\hline \multirow{2}{*}{ Sequencing } & First division & 2.48 & 0.64 & \multirow{2}{*}{0.97} & \multirow{2}{*}{0.33} \\
\hline & Premier & 2.72 & 1.65 & & \\
\hline \multirow{2}{*}{ Eye-Hand Coordination } & First division & 42.14 & 11.17 & \multirow{2}{*}{0.09} & \multirow{2}{*}{0.93} \\
\hline & Premier & 42.36 & 13.08 & & \\
\hline \multirow{2}{*}{ Visualization } & First division & 21.32 & 5.98 & \multirow{2}{*}{1.92} & \multirow{2}{*}{0.06} \\
\hline & Premier & 23.96 & 7.60 & & \\
\hline
\end{tabular}

\section{DISCUSSION AND CONCLUSION}

The present study aimed at investigating the visual skills in footballers. The results of the research, upon comparison of visual skills of footballers based on age, indicated that there was no meaningful difference in 
visual skills of accommodation/focusing, vergence, sequencing, eye-hand coordination, and visualization among footballers based on age group; however, there was a meaningful difference in visual skill of tracking among footballers, that is adults exhibited better performance compared to youths. The achieved results showed the fact that checking the conditions of players in different posts was of high importance, because it was dependent upon the match, strategy, opponent and needs of every player, thus requiring special training programs for different posts. Therefore, to achieve more successes, coaches and train designers should set their training programs based on the posts of players. The players, thus, in different posts have different physiological, anthropometric, psychological and visual needs, and selection of players is expected to be based on their superiority in the aforementioned cases (6).

Considering the former studies, no research was found to be directly consistent with the findings of this study; however, this study was consistent with part of findings of a research by DU Toit et al. (2009) which found an improvement in visual skill of tracking with age (17). The achieved result may be considered in different dimensions. A probable interpretation of the findings of the present study suggests a positive relationship between visual skill and sport activity (29). In other words, visual skills improved by sport (given central nervous system activity) due to increased processed stimuli by the brain, as a result of exercise and experience. Since participant footballers in this study were more experienced in tracking movements and were able to use the previously acquired behavioral patterns for the implementation of new skills, this resulted in an increase in the tracking movements and a decrease in the time of visual fixation from one point to another among athletes, also, it could be associated to the principle of transfer effect and the improvement in tracking skill performance, considering that the age group may be related to the aforementioned issue (30).

On the other hand and speaking by visualization, this difference may be associated with Saccade Suppression phenomenon. Since this tracking suppression occurs during the implementation of tracking movements, resulting in an efficiency only in the first and last points of tracking movements in the visual system; visual accommodation, thus, for a vision resolution in the mentioned points should move rapidly from the first point to the last, by using tracking movements (31). Faster tracking movements decreased the time duration of the information suppression and the athlete was provided with longer time spans for information acquisition and processing which contributed to the better performance in tracking skill (32).

The aforementioned difference could also be considered in terms of the motor growth in a way that the visual system of a child within the years of 10 to 12 develops structurally like that of adults, although it does not develop similarly in terms of function. This system, however, stabilizes in the third decade of the life. In this period, the visual system enjoys a high identification power in decision making, and movement selection and control. Experiencing the middle of the fourth decade of life, the visual system loses its flexibility (11).

Also, a comparison of the athletes' visual skills in terms of their posts during the match indicated that there was no meaningful difference in this regard. This was consistent with the results of a research by DU Toit et al. (2009) in which they found no meaningful difference between different posts in terms of visual skills of accommodation / focusing, tracking, circumference awareness, eye leaping movements and visual memory (17), and a research by Wimshurst, Sowden, and Cardinale (2012) in which they found no 
difference between visual skills of different posts among Olympic hockey players; however, when players were exposed to a computer program on visual skill, higher improvements were witnessed in goalkeepers compared to the other posts (18). In consistency of the present study with the aforementioned researches, the individual characteristics of the participants such as gender, and the type of sport, tools and the test could be taken into account.

In addition to the mentioned cases, the results of comparison of the footballers' visual skills in terms of records (Iranian Premier League and the First Division League) demonstrated no meaningful difference between visual skills of footballers. No research, which is directly consistent or inconsistent with the findings of this study, was found. The findings of this attempt were in agreement with those of former studies on lack of difference in visual skills in terms of posts during the match. It seems defining the posts in a football match requires more researches due to the long duration of time and the need for instant use of the players' capabilities in other posts.

It is advisable to note that the visual skills needed in different sports and posts are not solely limited to vigilance. There are other skills that affect the appropriate performance of the sport, such as perception of depth, accommodation/focusing, tracking, eye-hand coordination, color distinction, contrast sensitivity, visual reaction time, etc. (8). These skills, which are the keys to the success of any sport, are different in various sport posts, given the type and time duration of the respective sport. Generally speaking, an athlete fails to use his/her sport potentialities effectively if he/she, even with full physical preparation, is not able to benefit efficiently from the visual information. High strength, speed and agility cannot compensate for defective visual information (7). Also, for the best performance, an athlete should enjoy an appropriate visual performance in addition to possessing technique, tactic, and good physical preparation. Therefore, visual skills comprise one of the four main columns of intangible skills of an athlete which affect his/her success (8).

The current study presented information useful in identifying more requirements and results to be used as well. Because of limitations of implementing researches in this country, it seems this study and similar future researches may pave way for adopting a better and more accurate procedure to the present services to athletes, coaches, etc. and improve, finally, the performance through considering visual skills, their development, and also reducing additional expenses. No applied researches have been carried out on confirming or rejecting these studies, and this marks the significance of the aforementioned attempts.

\section{APPLICABLE REMARKS}

- It is suggested the need to hold courses and workshops in order to improve the awareness of coaches and athletes on visual skills and their effects on the performance of athletes.

- It is recommended also that coaches and athletes use this visual test as a field test, along with other clinical vision tests.

\section{REFFRENCES}

1. Malina RM, Eisenmann JC, Cumming SP, Ribeiro B, Aroso J. Maturity-associated variation in the growth and functional capacities of youth football (soccer) players 13-15 years. European journal of applied physiology. 2004;91(5-6):555-62. 
2. Wong P, Mujika I, Castagna C, Chamari K, Lau WC, Wisloff U. Characteristics of world cup soccer players. Soccer Journal. 2008;53(1):57-62.

3. Rampinini E, Coutts AJ, Castagna C, Sassi R, Impellizzeri FM. Variation in top level soccer match performance. International journal of sports medicine. 2007;28(12):1018-24.

4. Stolen T, Chamari K, Castagna C, Wisloff U. Physiology of soccer: an update. Sports medicine (Auckland, NZ). 2005;35(6):501-36.

5. Mediate P. Speed Training Concepts for the High School Coach and Athlete. Strength \& Conditioning Journal. 2008;30(1):65-6.

6. Brammer R. Football Skills: One-to-one Teaching for the Young Soccer Player: Right Way; 2008.126 p.

7. Mohammadi SF, Aghazade Amiri M, Naderifar H, Rakhshi E, Vakilian B, Ashrafi E, et al. Vision Examination Protocol for Archery Athletes Along With an Introduction to Sports Vision. Asian J Sports Med. 2016;7(1):1-9.

8. Wilson T, Falkel J. SportsVision eBook: Training for Better Performance: HUMAN KINETICS; 2004.

9. Abernethy B. Training the visual-perceptual skills of athletes. Insights from the Study of Motor Expertise. The American journal of sports medicine. 1996;24(6 Suppl):S89-92.

10. Cross ES, Stadler W, Parkinson J, Schutz-Bosbach S, Prinz W. The influence of visual training on predicting complex action sequences. Human brain mapping. 2013;34(2):467-86.

11. Kluka D. Visual skills: Considerations in learning motor skills for sport. ASAHPERD Journal. 1991;14(1):41-3.

12. Kluka D, Love P, Kuhlman J, Hammach G, Wesson M. The effect of a visual skills training program on selected collegiate volleyball athletes. International Journal of Sports Vision. 1996;3(1):23-34.

13. Pizzera A, Raab M. Perceptual Judgments of Sports Officials are Influenced by their Motor and Visual Experience. Journal of Applied Sport Psychology. 2012;24(1):59-72.

14. Atkins DL. The Eye and Sense of Vision 1998 [cited 2015]. Available from: http://lecerveau.mcgill.ca/flash/capsules/articles_pdf/sense_vision.pdf.

15. Abernethy B, Wood JM. Do generalized visual training programmes for sport really work? An experimental investigation. J Sports Sci. 2001;19(3):203-22.

16. Mcleod B. Effects Of Eyerobics Visual Skills Training Onselected Performance Measures Of Female Varsity Soccer Players. Perceptual and motor skills. 1991;72:863-6.

17. Du Toit PJ, Kruger PE, Chamane N, Campher J, Crafford D. Sport vision assessment in soccer players. African Journal for Physical, Health Education, Recreation and Dance. 2009;15(4):594-604.

18. Wimshurst ZL, Sowden PT, Cardinale M. Visual skills and playing positions of Olympic field hockey players. Perceptual and motor skills. 2012;114(1):204-16.

19. Calder S. LOOKS GOOD FOR HOCKEY: a new visual training program improves game skills in elite players 1997 [cited 2015]. Available from: http://www.sportsci.org/news/news9705/hockeyvision.html.

20. Ferreira J. An overview of research in sports vision: its history and an optometric perspective. South African Optometrist. 2003;62(4):142-9.

21. Abernethy B. Selective attention in fast ball sports. II: Expert-novice differences. Australian journal of science and medicine in sport. 1987;19(4):7-16.

22. Williams AM, Davids K, Williams JGP. Visual Perception and Action in Sport: Taylor \& Francis; 1999.441 p.

23. Da Silva CD, Bloomfield J, Marins JCB. A review of stature, body mass and maximal oxygen uptake profiles of U17, U20 and first division players in Brazilian soccer. Journal of Sports Science and Medicine. 2008;7(3):30919.

24. Gil SM, Gil J, Ruiz F, Irazusta A, Irazusta J. Physiological and anthropometric characteristics of young soccer players according to their playing position: relevance for the selection process. Journal of strength and conditioning research / National Strength \& Conditioning Association. 2007;21(2):438-45.

25. Du Toit PJ, Kruger PE, Naicker L-A, Govender C, du Preez T, Grobbelaar C, et al. Evaluation of visual skills in sedentary and active work environments. African Journal for Physical, Health Education, Recreation and Dance. 2012;18(1):178-91.

26. Du Toit PJ, Kruger PE, Tsotetsi A, Soma P, Govender C, Henning E, et al. Comparison of the performances of male and female armed services recruits under going sports vision testing. African Journal for Physical Health Education Recreation and Dance. 2012;Supplement 1:192-205.

27. Fourie J. An evaluation of the influence of Basic Military Training on the visual skills of recruits: University of Pretoria; 2013.

28. Mohammadi N, Rostami R, Alborzi M, editors. The Study of the Validity and Reliablility of Wilson \& Falkel (2004) Sports Vision Test Amongst the Female Students of Shiraz University. 8th International Congress on Physical Education and Sport Sciences; 2015; Tehran, Iran: Iranian Sport Sciences Research Institute.

Rostami, R., Mohammadi, H., Alborzi, M. (2015). Ann Appl Sport Sci, 3(4): 49-58. 
29. Ishigaki H, Miyao M. Differences in dynamic visual acuity between athletes and nonathletes. Perceptual and motor skills. 1993;77(3 Pt 1):835-9.

30. Hazel CA. The efficacy of sports vision practice and its role in clinical optometry*. Clinical and Experimental Optometry. 1995;78(3):98-105.

31. Jafarzadehpur E, Aazami N, Bolouri B. Comparison of saccadic eye movements and facility of ocular accommodation in female volleyball players and non-players. Scandinavian journal of medicine \& science in sports. 2007;17(2):186-90.

32. Paul M, Biswas SK, Sandhu JS. Role of sports vision and eye hand coordination training in performance of table tennis players. Brazilian Journal of Biomotricity. 2011;5(2):106-16. 
تازههاى علوم كاربردى ورزش

مقاله اصيل

دوره سوم، شماره جهارم كاري

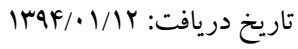

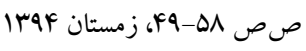

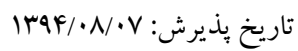

\title{
ارزيابى و مقابسه مهاربتهاى بينايى در فوتباليستها 'ربابه رستمى *، "حميد محمدى، "محبوبه البرزى
}

\author{
I. استاديار رفتار حركتى، گروه تربيت بدنى و علوم ورزشى، دانشگاه شيراز، شيراز، ايران.

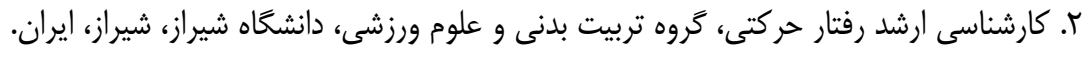

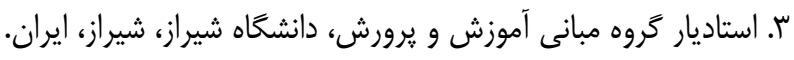

جكيده

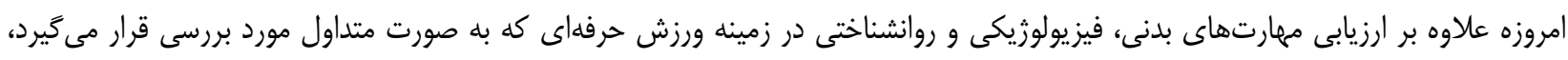

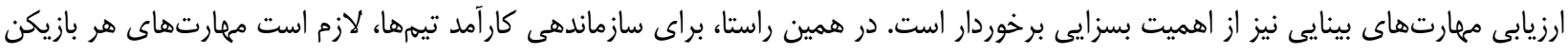

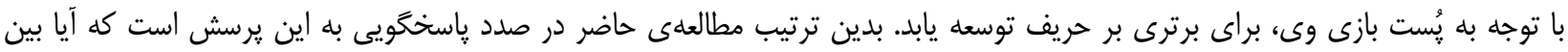

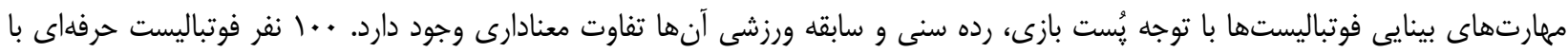
ميانگين سن، لو/

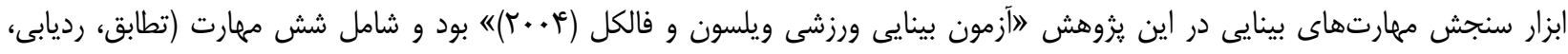

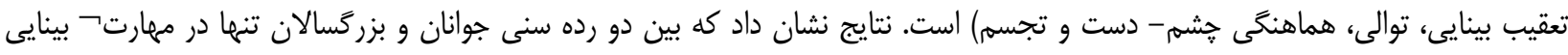

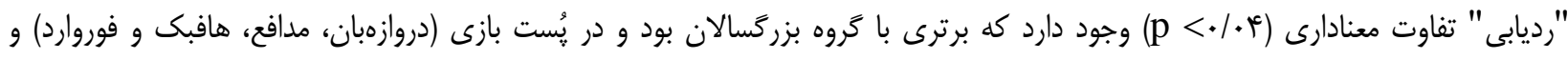

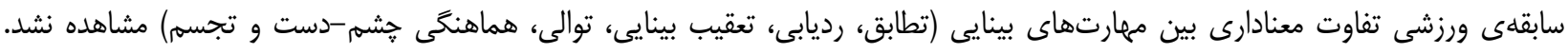
نتايج اين يزوهش نشاندهندة يكسان بودن برنامه تمرينى اعضاى تيه مى ياشد؛ در صورتى

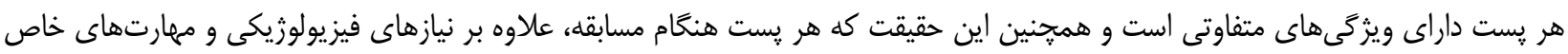

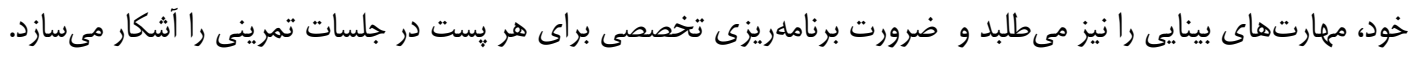
وازَّان كليدى: مهارتهاى بينايى، فوتباليستها، ارزيابى.

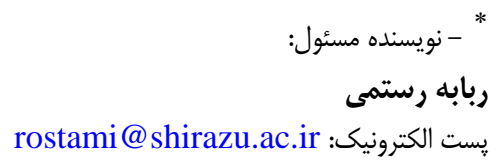

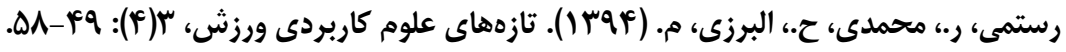

